\title{
Treatment of chronic osteomyelitis of the femur with combined technique
}

\author{
Kronik femur osteomiyelitinin kombine teknikle tedavisi
}

\author{
Deniz Gülabi, M.D., ${ }^{1}$ Mehmet Erdem, M.D., ${ }^{2}$ Gültekin Sıtkı Çeçen, M.D. ${ }^{1}$ \\ 1Department of Orthopedics and Traumatology, Dr. Lütfi Kırdar Kartal Training and Research Hospital, İstanbul, Turkey \\ ${ }^{2}$ Department of Orthopedics and Traumatology, Medical Faculty of Sakarya University, Sakarya, Turkey
}

Treatment of chronic osteomyelitis of the long bones is challenging due to infection and bone resection. The aim of this case presentation is to report an alternative method for chronic osteomyelitis of the femur. We aimed to provide acute and rapid shortening at the resected site, and lengthening from the metaphyseal bone of a 22-year-old male patient who applied with pain and discharge in the right thigh due to chronic osteomyelitis, and who had undergone three surgical procedures previously. A two-stage treatment was planned. At the first stage, bone resection, antibiotic-impregnated cement rod, and external fixator were applied. At the second stage, intramedullary femoral nail was applied, compression was continued to achieve the docking side in the resection area, and lengthening was performed to eliminate shortness. At the final follow-up, excellent bone and functional scores were obtained. The distraction-compression technique described here can provide successful results in the treatment of chronic osteomyelitis of the long bones.

Keywords: Femur; lengthening; osteomyelitis.
Uzun kemiklerin kronik osteomiyelitinin tedavisi, enfeksiyon ve kemik rezeksiyonu nedeniyle zordur. $\mathrm{Bu}$ olgu sunumunun amac1, kronik femur osteomiyelitinin tedavisinde alternatif bir yöntem sunmaktır. Sağ uyluğunda kronik osteomiyelit sonucu ağrı ve akıntı ile başvuran ve daha önce üç cerrahi işlem geçiren 22 yaşında erkek hastanın rezeksiyon bölgesinde akut ve hızlı kısaltma sağlayıp, metafizer bölgeden uzatmayı amaçladık. İki aşamalı tedavi planlandı. Birinci aşamada, kemik rezeksiyonu, antibiyotik emdirilmiş çimentolu rod ve eksternal fiksatör uygulandı. İkinci aşamada, intramedüller femur çivisi uygulandı, rezeksiyon bölgesinde kemik temasını sağlamak için kompresyona devam edildi ve kısalı̆̆ önlemek için uzatma uygulandı. Son takipte mükemmel kemik skorları ve fonksiyonel skorlar elde edildi. Tanımlamış olduğumuz distraksiyon-kompresyon yöntemi, uzun kemiklerin kronik osteomiyelitinin tedavisinde başarılı sonuçlar sağlayabilir.

Anahtar sözcükler: Femur; uzatma; osteomiyelit.
Orthopedic treatment of chronic osteomyelitis of the long bones is challenging due to infection and bone resection. ${ }^{[1]}$ A two-stage operation was proposed to treat such challenging cases. ${ }^{[2]}$ The aim of this case presentation is to report an alternative treatment method for chronic sclerosing osteomyelitis in the long bones. Our technique is a gradual bifocal bone transport that depends on the concept of compression and distraction. This technique was reported previously by Giebel, ${ }^{[3]}$ and Gauzy et al. ${ }^{[4]}$ later popularized it. In the current technique, the primary aim is acute and rapid shortening at the resected side to gain cross-sectional bone contact and prevent docking-side pseudoarthrosis, and lengthening from the proximal and distal metaphyseal bone. We evaluated external fixation time, external fixator index, and time to union on plain radiographs, clinical results using bone and functional assessment scores, and postoperative complications from chart review.

\section{CASE REPORT}

A 22-year-old male patient presented with pain and discharge in the right thigh due to chronic sclerosing osteomyelitis. The patient had previously undergone three surgical procedures for treatment of a grade 2 open femoral fracture. Informed consent was obtained from the patient for participation. Closed reduction

- Received: December 18, 2013 Accepted: March 24, 2014

- Correspondence: Deniz Gülabi, M.D. Dr. Lütfi Kırdar Kartal Eğitim ve Araştırma Hastanesi, Ortopedi ve Travmatoloji Kliniği, 34890 Kartal, İstanbul, Turkey Tel: +90 532 - 3654768 Fax: +90 216-305 5110 e-mail: dgulabi@yahoo.com 


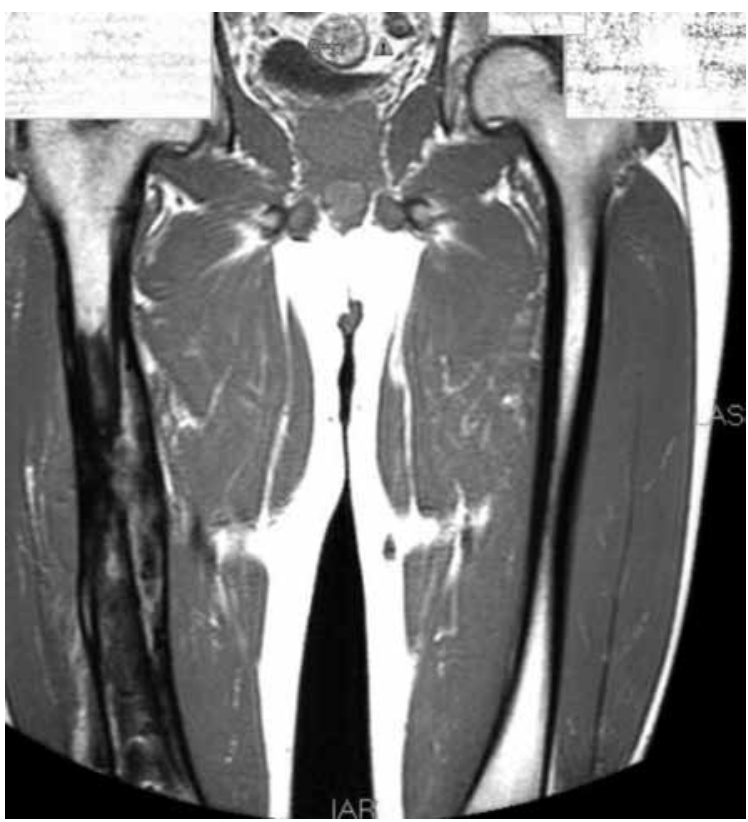

Figure 1. Preoperative $T_{2}$ magnetic resonance imaging coronal scan of the femur due to chronic osteomyelitis.

and stabilization with unilateral external fixation were performed as part of the initial treatment. When this treatment method failed at the six-month follow-up examination, it was replaced with intramedullary nailing. This method resulted in septic union. The patient underwent a third operation for removal of the femoral nail, and debridement of the infected areas. Preoperative C-reactive protein (CRP) level and erythrocyte sedimentation rate (ESR) were high. C-reactive protein was $14.8 \mathrm{mg} / \mathrm{L}$ (reference 0-5.00), and ESR was $32 \mathrm{~mm} / \mathrm{h}$ (reference 6-12). The operative procedure was performed in two stages.

In the first stage, a bone resection of $150 \mathrm{~mm}$ in length was planned based on preoperative radiological images (radiographs, magnetic resonance imaging and computed tomography scans) (Figures 1, 2). The patient was placed in the supine position on a radiolucent table. A wide lateral incision was made including the sinus tract. Bone resection was performed until the paprika sign (bleeding area) in the bone was seen and deep tissue culture was taken. After debridement and irrigation, an antibiotic-impregnated polymethylmethacrylate cement rod (4 $\mathrm{g}$ teicoplanin added to $2 \times 40 \mathrm{mg}$ gentamicin cement) was inserted in place of a nail, and custom-made antibiotic-impregnated polymethylmethacrylate beads were placed in the defect area. Hydroxyapatite (HA)-coated Schanz screws were placed to each segment proximally and distally. A unilateral fixator (LRS; Tasarimmed,

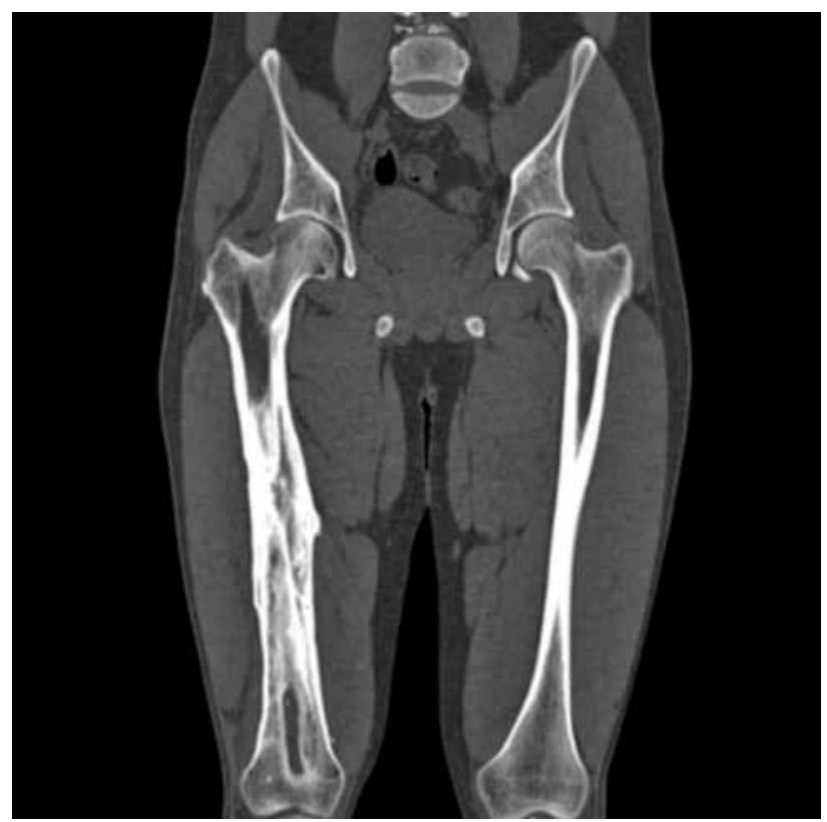

Figure 2. Preoperative frontal computed tomography scan of the femur due to chronic osteomyelitis.

Topkapi, Istanbul, Turkey) was applied to stabilize the femur (Figure 3, 4).

The postoperative culture result showed proliferation of methicillin-resistant Staphylococcus aureus, so in consultation with the infection clinic, treatment with intramuscular teicoplanin $2 \times 400 \mathrm{mg} /$ day was started. After six weeks of treatment, the combined-technique phase was carried out when the patient's CRP and ESR values decreased to within normal limits (ESR: $8 \mathrm{~mm} / \mathrm{h}, \mathrm{CRP}: 3.8 \mathrm{mg} / \mathrm{L}$ ).

In the second stage, the patient was placed in the supine position on a radiolucent table, with his limbs in a scissors position. A percutaneous biopsy was performed, and the specimen was sent for Gram staining and frozen-section analysis to indicate resolution of infection. After the verification of the resolution of the infection, the antibiotic rod and

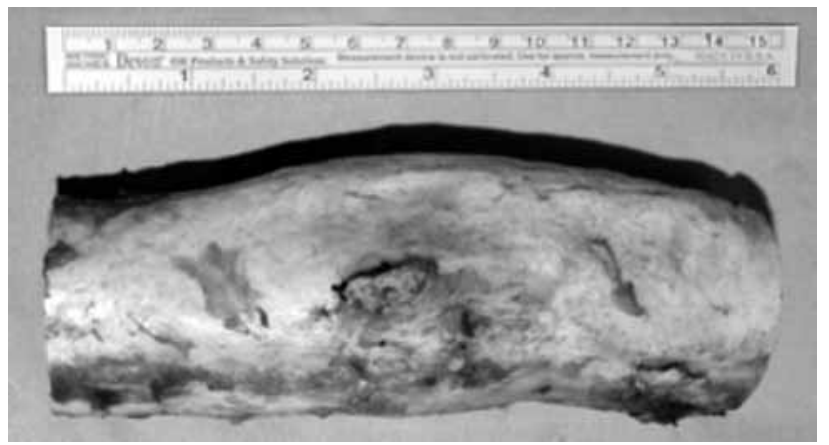

Figure 3. Image of the resected femoral segment. 
beads were removed. An antegrade intramuscular (IM) trochanteric nail (Trigen; Smith \& Nephew, Memphis, TN, USA) $380 \mathrm{~mm}$ long and $11.5 \mathrm{~mm}$ thick was prepared from the preoperative template, and additional locking holes were created at the planned site of locking of the segment upon the completion of bone transport to prevent recoil of the segment. ${ }^{[1]}$ The proximal and distal femoral osteotomy areas were drilled percutaneously and osteotomy areas were completed with osteotomes for the bifocal lengthening procedure. The femoral nail guide wire was inserted from the great trochanteric tip, and the medullary canal was reamed so as to be $2.0 \mathrm{~mm}$ larger than the planned size of the nail. The nail was inserted, the distal end locked, and block screws were placed to increase stability. The proximal end was not locked. In addition to the previously inserted Schanz screws, two further HA Schanz screws were inserted into the proximal and distal lengthening segment (Figure 5). To prevent the contact of Schanz screw with the nail, we used the cannulated drill-bit technique described by Paley et al..$^{[5]}$ The defect region was shortened acutely by $60 \mathrm{~mm}$, which was performed while the filling of the tibialis anterior and tibialis posterior vessels was measured with a sterile Doppler instrument and the capillary circulation monitored.
To prevent subsequent circulatory problems, compression of $2 \mathrm{~mm} /$ day was planned to complete the remaining shortening on the docking side, which would be continued for 45 days until the docking-side area closed $(90 \mathrm{~mm})$. During this period, the patient was closely monitored to avoid any circulation problems. On day 15 after the osteotomy, ${ }^{[6]}$ lengthening was started from the osteotomy regions at $3 \times 0.25 \mathrm{~mm} /$ day (total $1.5 \mathrm{~mm} /$ day) for the bifocal bone transport, and the patient was discharged as an outpatient with polyclinic follow-up.

After 45 days of compression, closure of the docking side in the defect area was obtained, and the patient underwent grafting of the area with an autogenous graft taken from the iliac wing. Owing to the stress loaded on the Schanz screws in the distal lengthening area, a further $6.5 \mathrm{~mm}$ HA Schanz screw was added. At the end of the lengthening process a total of $170 \mathrm{~mm}$ of lengthening $(150 \mathrm{~mm}$ for bone resection and $20 \mathrm{~mm}$ for preoperative leg discrepancy) was obtained. The proximal end of the nail was locked with screws, and stability was increased by block screws. The custom-made locking holes of the nail were also locked with screws inserted

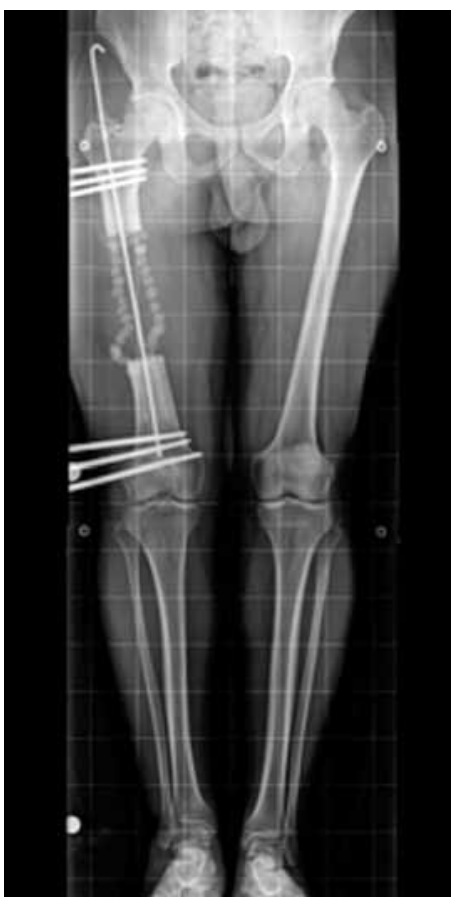

Figure 4. Postoperative anteroposterior radiography of the femur, after the resection of $15 \mathrm{~cm}$ femur, application of the intramedullary rod that was augmented with cement and antibiotics.

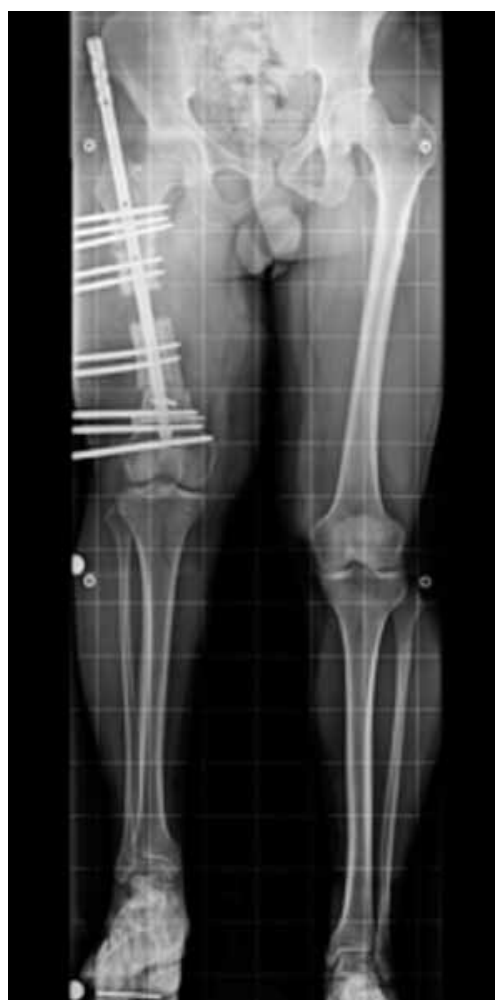

Figure 5. Postoperative anteroposterior standing orthoradiography of the patient after second stage operation. 


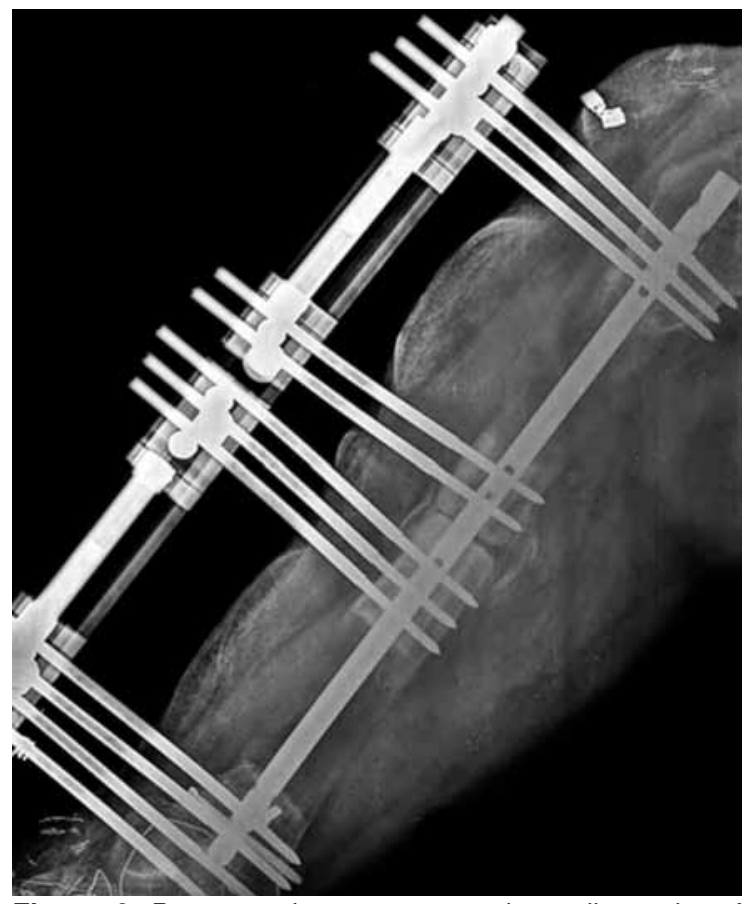

Figure 6. Postoperative anteroposterior radiography of the patient at 5.5 months follow-up, before the removal of external fixator.

percutaneously. Then the unilateral external fixator was removed (Figure 6, 7).

During the postoperative radiologic follow-ups, conventional radiographs were made every two weeks during the distraction phase and once a month during the consolidation phase. Anteroposterior and lateral 14x17-inch image radiographs of the femur were used to determine the bone union and consolidation. External fixator index was defined as the duration of external fixation in months divided by the total amount of bone transported and/or the amount of lengthening in millimeters. Radiographic union was defined as the presence of callus in three of the four cortices as seen on anteroposterior and lateral radiographs.

During the postoperative follow-up, a minor complication, namely pin-site infection, according to the Paley classification, ${ }^{[7]}$ developed in two Schanz screws. This was resolved with wound-care dressings. No neurovascular pathology occurred in the patient either perioperatively or in the follow-up period. During the acute shortening stage, the patient experienced nail-related irritation in his right buttock, resulting from the proximal sliding of the nail outside the bone. This was resolved when the nail reached its ideal place together with the lengthening. From the first operation onwards, the patient was mobilized

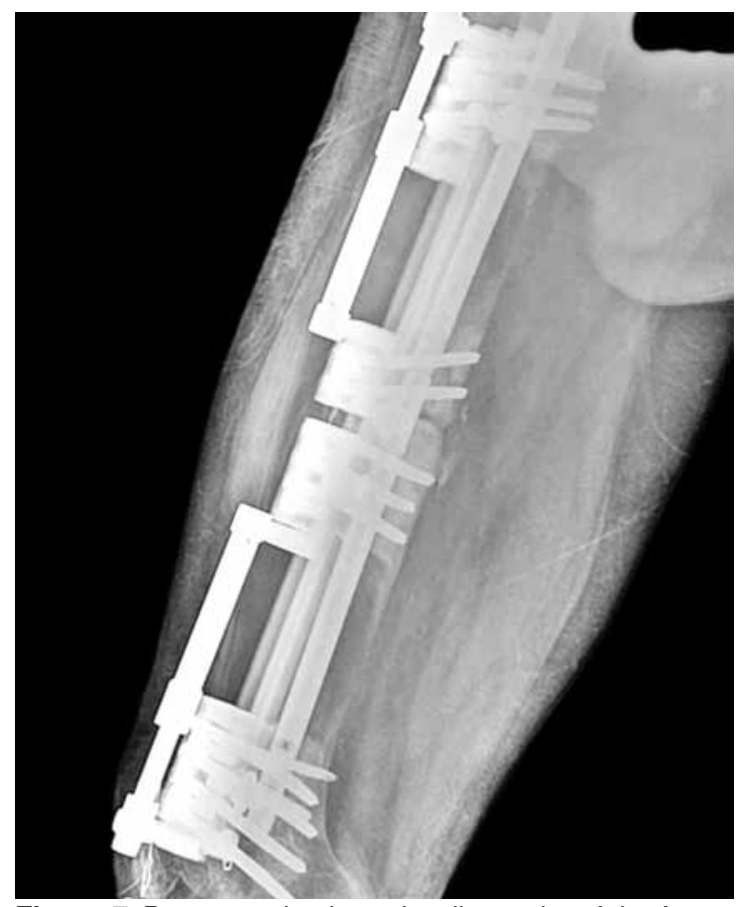

Figure 7. Postoperative lateral radiography of the femur at 5.5 months follow-up, before the removal of external fixator.

with full weight bearing, with compensation for the shortness. The preoperative range of motion (ROM) in the knee was $0-80^{\circ}$, which decreased to $0-70^{\circ}$ in the postoperative period. During the final operation, the external fixator was removed, and redressement force was applied to the knee. With aggressive physiotherapy, a knee ROM of $0-90^{\circ}$ was attained.

At the postoperative follow-up examination in month 19, excellent bone and functional scores were obtained according to the Paley classification, ${ }^{[5,8]}$ The external fixator time (EFT) was 5.6 months, and the external fixation index (EFI) was 0.032 months per $\mathrm{mm}$ for $170 \mathrm{~mm}$ lengthening in this case. The time to union for the docking side was 3.5 months. Erythrocyte sedimentation rate was $6 \mathrm{~mm} / \mathrm{h}$, CRP was $2.0 \mathrm{mg} / \mathrm{L}$ at the last follow-up (Figure 8,9 ). The patient returned to his pre-injury job.

\section{DISCUSSION}

Bone transport has been more common in recent years. Our technique is a gradual bone transport that depends on the concept of compression-distraction described by Ilizarov. ${ }^{[9]}$ The major advantage of this current technique is using an intramedullary nail with external fixator, which overcomes the problems of shortening, plastic deformation, angular deformity and fracture of the regenerated bone. ${ }^{[1,10-12]}$ Compared with the classic external fixator technique, 


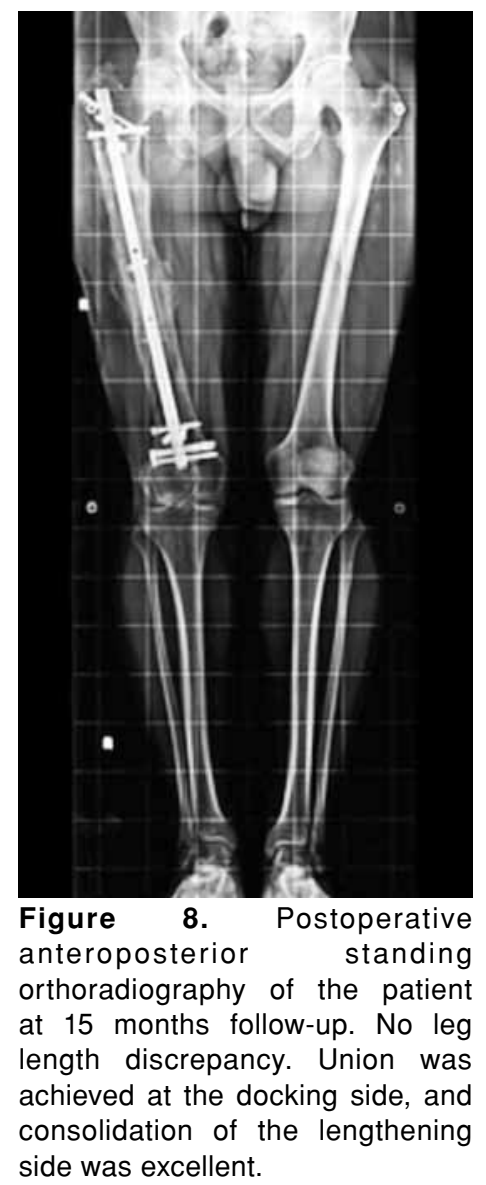

this combined technique achieved significantly reduced EFT, EFI, and consolidation index. Early removal of the external fixator reduces the risk of pin-site infection and allows for early rehabilitation of the patient. ${ }^{[1,11-13]}$ In our case, the patient had two minor complications according to the Paley classification, ${ }^{[7]}$ which were resolved without any additional surgery. Angulation and translations have been reported as possible complications of bone transport procedures. ${ }^{[14]}$ In our case, we did not observe any deformity due to the unilateral external fixator. Paley et al. ${ }^{[5]}$ reported fracture of the regenerated bone after limb lengthening. Song et al. ${ }^{[10]}$ demonstrated refractures after deformity correction when an intramedullary nail had not been used, and no fractures when an intramedullary nail had been used. Kocaoglu et al. ${ }^{[11]}$ did not encounter any refractures or recurrences of the deformities in their series.

The shortening beyond $50 \mathrm{~mm}$ should be performed at the rate of $2 \mathrm{~mm}$ per day via compression on the external fixator. However, this increases the possibility of nonunion and delayed union because of soft tissue invagination in the docking-side area.

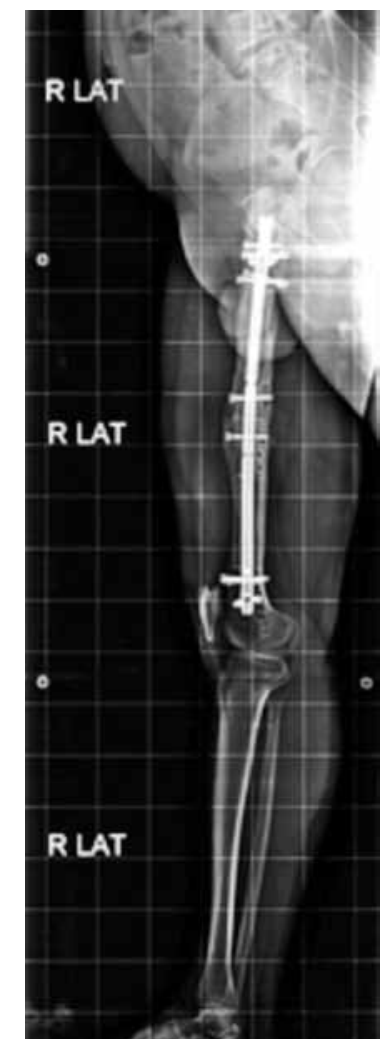

Figure 9. Postoperative lateral orthoradiography of the femur at 15 months follow-up.

Sala et al. ${ }^{[6]}$ reported that in their study group consisting of 12 cases, docking-side revision with autogenous bone grafting was necessary in $83 \%$ of cases. Lowenberg et al. ${ }^{[15]}$ reported a rate of $8.8 \%$ for docking-side nonunion even though they performed autogenous bone grafting at the docking side. Cierney and Zorn ${ }^{[16]}$ recommended the use of an autogenous bone graft in cases of nonunion with more than $60 \mathrm{~mm}$ segmental bone loss defect. In our case, this problem was resolved by using an autograft in the docking-side area, and no delayed union or nonunion occurred.

One disadvantage of this technique is the prominence of the proximal part of the nail, which caused irritation in our patient's buttocks during the acute compression phase of the treatment. Eralp et al. ${ }^{[1]}$ also reported this problem with their technique, which used retrograde intramedullary nailing. In our case, this was resolved once the nail reached its ideal place, together with the lengthening.

The advantage of this technique is that it provides cross-sectional bone contact in the docking side quicker than the classical bone transport. This prevents nonunion related to the soft tissue invagination in 
the docking side such as infection and tumor which necessitate wide resection.

\section{Conclusion}

The combined technique of distraction and osteogenesis described here is a beneficial alternative for the treatment of chronic osteomyelitis in the long bones.

\section{Declaration of conflicting interests}

The authors declared no conflicts of interest with respect to the authorship and/or publication of this article.

\section{Funding}

The authors received no financial support for the research and/or authorship of this article.

\section{REFERENCES}

1. Eralp L, Kocaoglu M, Rashid H. Reconstruction of segmental bone defects due to chronic osteomyelitis with use of an external fixator and an intramedullary nail. Surgical technique. J Bone Joint Surg Am 2007;89 Suppl 2 Pt.2:183-95.

2. Demiralp B, Yıldırım C, Yurttaş Y, Çiçek EI, Başbozkurt M. Lower limb salvage surgery using Ilizarov circular external frame for a landmine injury about the knee. Eklem Hastalik Cerrahisi 2013;24:41-5.

3. Giebel G. Resection debridement of the lower leg with compensatory callus distraction. Unfallchirurg 1991;94:4018. [Abstract]

4. Sales de Gauzy J, Vidal H, Cahuzac JP. Primary shortening followed by callus distraction for the treatment of a posttraumatic bone defect: case report. J Trauma 1993;34:461-3.

5. Paley D, Herzenberg JE, Paremain G, Bhave A. Femoral lengthening over an intramedullary nail. A matched-case comparison with Ilizarov femoral lengthening. J Bone Joint Surg [Am] 1997;79:1464-80.

6. Sala F, Thabet AM, Castelli F, Miller AN, Capitani D, Lovisetti $\mathrm{G}$, et al. Bone transport for postinfectious segmental tibial bone defects with a combined ilizarov/taylor spatial frame technique. J Orthop Trauma 2011;25:162-8.

7. Paley D. Problems, obstacles, and complications of limb lengthening by the Ilizarov technique. Clin Orthop Relat Res 1990;250:81-104.

8. Paley D, Catagni MA, Argnani F, Villa A, Benedetti GB, Cattaneo R. Ilizarov treatment of tibial nonunions with bone loss. Clin Orthop Relat Res 1989;241:146-65.

9. Ilizarov GA. Clinical application of the tension-stress effect for limb lengthening. Clin Orthop Relat Res 1990;250:8-26.

10. Song HR, Soma Raju VV, Kumar S, Lee SH, Suh SW, Kim JR, et al. Deformity correction by external fixation and/or intramedullary nailing in hypophosphatemic rickets. Acta Orthop 2006;77:307-14.

11. Kocaoglu M, Eralp L, Bilen FE, Balci HI. Fixator-assisted acute femoral deformity correction and consecutive lengthening over an intramedullary nail. J Bone Joint Surg [Am] 2009;91:152-9.

12. Eralp L, Kocaoglu M, Yusof NM, Bulbul M. Distal tibial reconstruction with use of a circular external fixator and an intramedullary nail. The combined technique. J Bone Joint Surg [Am] 2007;89:2218-24.

13. Bilen FE, Kocaoglu M, Eralp L, Balci HI. Fixator-assisted nailing and consecutive lengthening over an intramedullary nail for the correction of tibial deformity. J Bone Joint Surg [Br] 2010;92:146-52.

14. Harzenberg JE, Paley D. Tibial lengthening over nails(LON). Techniques in Orthopaedics 1997;12:250-9.

15. Lowenberg DW, Buntic RF, Buncke GM, Parrett BM. Longterm results and costs of muscle flap coverage with Ilizarov bone transport in lower limb salvage. J Orthop Trauma 2013;27:576-81.

16. Cierny G 3rd, Zorn KE. Segmental tibial defects. Comparing conventional and Ilizarov methodologies. Clin Orthop Relat Res 1994;301:118-23. 